\title{
Estimation of $\alpha$-pinene absorption in the Japanese resident based on toxicokinetic analysis in rats by inhalation exposure
}

\author{
Toshiaki YOSHIDA
}

Osaka Prefectural Institute of Public Health, 1-3-69, Nakamichi, Higashinari-ku, Osaka 537-0025, Japan

\section{日本の住宅内での $\alpha$-ピネン吸収量の推定 一吸入曝露ラットにおける体内動態の薬物動力学的解析から一}

\author{
吉 田 俊 明
}

大阪府立公衆衛生研究所 $=537-0025$ 大阪市東成区中道1-3-69

\begin{abstract}
$\alpha$-Pinene is a major compound contributing to indoor air pollution in Japanese residences together with many aliphatic or aromatic hydrocarbons. In the present study, the amounts of each enantiomer of $\alpha$-pinene ((+)- and (-)- $\alpha$ pinene) absorbed by a resident in a Japanese home were estimated by evaluating their inhalation toxicokinetics in rats. Measured amounts of the substances were injected into a closed chamber system in which a rat had been placed, and the concentration changes in the chamber were examined. The toxicokinetics of the substances were evaluated based on concentration-time courses using a nonlinear compartment model. The absorption amounts per unit time in rats exposed to the substances at constant concentration were simulated using the estimated values of the toxicokinetic parameters. The estimated amounts for the two enantiomers showed approximate agreement. When the values were compared with those for aliphatic or aromatic hydrocarbons examined in our previous studies, $\alpha$-pinene was estimated to be absorbed more easily by inhalation than $n$-hexane, $n$-heptane, $n$-nonane, $n$-decane, toluene, xylenes, ethylbenzene and styrene, and to be absorbed about the same level as 1,2,4-trimethylbenzene. Their absorption amounts in human residents were extrapolated from the results for rats and the residential concentrations found in our previous study. The total amount of the two enantiomers absorbed was estimated to be $31 \mu \mathrm{g} / 60 \mathrm{~kg}$ of human body-weight while at home for $16 \mathrm{~h}$ (residential concentration: $4.4 \mu \mathrm{g} / \mathrm{m}^{3}$ as median value). The value was the highest after that for toluene. Similarly, in a residence where air pollution was marked, the absorption amount of $\alpha$ pinene ( $13 \mathrm{mg}$ for $16 \mathrm{~h}$ in a residence with an indoor maximum concentration of $1.8 \mathrm{mg} / \mathrm{m}^{3}$ ) was estimated to be much more than those of other substances. The value $(13 \mathrm{mg})$ was the same level as the tolerable daily intake (TDI) calculated from the No Observed Adverse Effect Level (NOAEL) proposed by the Environmental Protection Agency (EPA).
\end{abstract}

\section{要 旨}

$\alpha$-ピネンは, 多くの脂肪族及び芳香族炭化水素と同様に日本の住宅内の空気污染に関与する主要な化学物

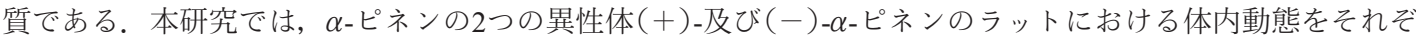
れ薬物動力学的に解析し，ヒトに打ける経気道吸収量を外挿した。ラットを入れた閉鎖系曝露装置内に一定 量の $\alpha$-ピネンを注入後気化させ，ラットへの吸入による装置内濃度推移を調べ，薬物動力学的に解析した。 得られた結果から，一定濃度の $\alpha$-ピネンに一定時間曝露されたラットにおける吸収量を推定したところ，異 性体間で差は認められなかった。ラットにおける炭化水素類の経気道吸収量について過去に我々が得た結果 と比較すると, 同一の曝露濃度下に打いて $\alpha$-ピネンは $n$-ヘキサン, $n$-デカン, トルェン, キシレン, エチル ベンゼン，スチレンなどよりあ吸収されやすく，1,2,4-トリメチルベンゼンと同程度であると推定された。 ラットから得た結果及び日本の住宅に抢ける各物質の室内濃度に関する過去の調査結果をもとに，居住者 (体重60 kg)に抢ける $\alpha$-ピネンおよび各炭化水素類の吸収量を推定した。16時間の在宅時間中の $\alpha$-ピネン吸 収量(住宅内濃度中央值 $4.4 \mu \mathrm{g} / \mathrm{m}^{3}$ において $31 \mu \mathrm{g}$ ) は，トルエンに次いで多かった。また，各物質による空気 污染の著しい住宅居住者の $\alpha$-ピネン吸収量(住宅内濃度 $1.8 \mathrm{mg} / \mathrm{m}^{3}$ において $13 \mathrm{mg}$ ) は他の物質の吸収量より もはるかに多く，米国環境保護庁(EPA)の提案する $\alpha$-ピネンの無毒性量 (NOAEL)から算出した耐容一日摂 取量(TDI) と同レベルであった。

Key words: $\alpha$-pinene ( $\alpha$-ピネン), indoor air pollution(室内空気污染), extrapolation(外挿), closed chamber system(閉鎖系曝露装置), residence(住宅), toxicokinetics(毒物 動力学) 


\section{INTRODUCTION}

The indoor air of residences is contaminated by a great variety of chemical compounds diffusing from building products and interior materials. Adverse effects on human health due to exposure to these airborne substances in residences are of concern because much time is spent at home. The average person in Japan is estimated spend about 16 hours a day at home $^{1)} . \alpha$-Pinene, as well as $p$-dichlorobenzene and hydrocarbons such as toluene, was demonstrated to be a ubiquitous compound in residential air and to be a major compound contributing to indoor air pollution in $\mathrm{Japan}^{2-5)}$. In some buildings, marked indoor air pollution due to $\alpha$-pinene has been suggested to contribute to the sick building syndrome (SBS) ${ }^{6-8)}$. In addition, $\alpha$-pinene was shown to be significantly related to SBS in newly built Japanese dwellings ${ }^{9,10}$. Our previous study, which examined indoor air pollution in 105 residences of Osaka prefecture, found significantly higher concentrations of $\alpha$-pinene in wooden houses than in steelframed houses and in houses of up to 2 years after completion than in those of more than 3 years ${ }^{3}$. Therefore, building products were considered to be the major source of indoor air pollution by $\alpha$-pinene, although $\alpha$ pinene is also a major component of turpentine oil used as solvents for paints and varnishes. We found a maximum $\alpha$-pinene concentration of $1.8 \mathrm{mg} / \mathrm{m}^{3}$ as the average concentration over $24 \mathrm{~h}$ under usual living conditions among 79 volatile compounds determined for all residences examined.

The guideline value for indoor $\alpha$-pinene is not given by the Japanese government or the World Health Organization (WHO), although Seifert ${ }^{11)}$ proposed a guideline value of $30 \mu \mathrm{g} / \mathrm{m}^{3}$ as the maximum indoor concentration of the sum of individual terpenes under normal conditions, not special circumstances. $\alpha$-Pinene, which occurs naturally in pine, fir and spruce trees ${ }^{12)}$, is one of the monoterpenes and is a mixture of two enantiomers $((+)$ - and (-)- $\alpha$-pinene). $\alpha$-Pinene causes irritation of the eyes, nose and throat, palpitation, dizziness, nervous disturbances, chest pain and nephritis ${ }^{13,14)}$ and has been shown to be a tumor promoter in animal studies ${ }^{15,16)}$. $(+)-\alpha$-Pinene has been demonstrated to be more potent as a sensory irritant than $(-)-\alpha$-pinene ${ }^{17,18)}$.
Knowledge about daily absorption amounts of airborne $\alpha$-pinene in humans while at home is very important to evaluate the adverse effects on health due to exposure to it. However, there has been no report in which the absorption amounts of $\alpha$-pinene in the residents were discussed. In general, the amounts of volatile substances absorbed by inhalation are obtained by multiplying their exposure concentrations measured by respiratory minute volumes (pulmonary ventilation) cited from previous references. However, the absorption amounts per unit time of the substances by inhalation depend on their affinities for tissues and clearances from the body, that is, the absorption amounts are larger for substances that disappear rapidly by hepatic metabolism and renal elimination, and also for lipophilic substances with high affinities for tissues ${ }^{19-21)}$. Therefore, understanding the toxicokinetics for each substance is essential for accurate estimation of their absorption amounts. However, knowledge of the inhalation toxicokinetics for $\alpha$-pinene in humans is limited ${ }^{13)}$, though there have been several reports on exposure to terpenes in workers handling wood ${ }^{22-24)}$. Falk et al. ${ }^{13)}$ examined the uptake, distribution and elimination of $(+)-$ or (-)- $\alpha$-pinene in human volunteers subjected to inhalation exposure $\left(10,225\right.$ and $450 \mathrm{mg} / \mathrm{m}^{3}$ during light physical exercise for $2 \mathrm{~h}$ ). The pulmonary uptake rates of $\alpha$-pinene were calculated as the difference between its amount in inhaled and exhaled air, and the mean value of the results measured periodically four times during $2 \mathrm{~h}$ was used to calculate the total $\alpha$-pinene uptake during the entire exposure period. Although the uptake rates were presumed to vary markedly with time immediately after the start of the inhalation as the rates were considered to change with the amount of $\alpha$-pinene accumulated in the body by inhalation, this matter was not considered in the study by Falk et al. ${ }^{13)}$. In addition, the values of the uptake rates determined by them varied markedly from 40 to $60 \%$ among exposure concentrations. Therefore, the knowledge obtained from the study was insufficient to accurately estimate the amounts absorbed in residents exposed to $\alpha$-pinene. Although it was advisable to examine in human volunteers for the estimation, it was difficult to structure an exposure system in which the desired exposure 
dose could be adjusted for the volunteers and the animal experiment is necessary. There also has been no report on the inhalation toxicokinetics of $\alpha$-pinene for animals that would allow extrapolation of the absorption amounts for humans.

In previous studies, we established a method for estimating the amounts of volatile organic compounds, aliphatic or aromatic hydrocarbons, diffusing from the interior materials, absorbed by a driver in an automobile cabin by examining the inhalation toxicokinetics of the substances in rats, and verified the usefulness of the method $^{19,25)}$. In the present study, we used our method to estimate the amounts absorbed by humans exposed to each of the two enantiomers of $\alpha$-pinene at home in order to obtain basic data for evaluating the health effects of exposure to $\alpha$-pinene on Japanese residents under usual living conditions. The results were compared with the absorption amounts for human residents calculated for the above-mentioned aliphatic or aromatic hydrocarbons, which were among the major compounds contributing to residential air pollution, by using toxicokinetic data obtained previously. The absorption amounts could be more accurately compared among the substances by using the same method.

\section{MATERIALS AND METHODS}

\section{1. Chemicals}

(1R)-(+)- $\alpha$-Pinene (CAS no.: 7785-70-8, purity: > $95 \%)$ and (1S)-(-)- $\alpha$-pinene (7785-26-4, > 96.0\%) were obtained from Tokyo Kasei Kogyo (Tokyo, Japan). Phosphoric acid was purchased from Wako Pure Chemical (Osaka, Japan), and Ascarite II (92\% sodium hydroxide, 8-20 mesh) from Arthur H. Thomas (NJ, USA). The animals were euthanized using Somnopentyl, containing $64.8 \mathrm{mg} / \mathrm{ml}$ of pentobarbital sodium, which was purchased from Pitman-Moore (IL, USA). Gases (oxygen, nitrogen, hydrogen and air) were obtained from Naniwa Sanso (Osaka, Japan).

\subsection{Equipment}

The closed chamber system shown in Fig. 1 was set up in our laboratory. It was kept at room temperature of $25^{\circ} \mathrm{C}$ and used for repeated determination of the concentrations of $(+)$ - and $(-)-\alpha$-pinene in the chamber air.
The system consisted of a 2.7-L glass desiccator jar in which a rat was placed, a chilled vial $\left(c a .1^{\circ} \mathrm{C}\right)$ containing phosphoric acid as a trap for water from exhalation and ammonia from excrement by a cool stirrer (As-one model CPS-30, Osaka, Japan), a glass tube $(300 \times 21$ mm i.d.) packed with Ascarite II to absorb the exhaled carbon dioxide, a 10-L Tedlar (polyvinyl fluoride) bag containing oxygen with a water trap to replenish oxygen decreased by respiration, a micro pump (flow rate $200 \mathrm{ml} / \mathrm{min}$, reconstructed Enomoto model DM-403 ST, Tokyo, Japan) for circulation of the air in the chamber, and an electromagnetic-switching six-way valve equipped with a sampling loop of $1.0 \mathrm{ml}$ (Shimadzu, Kyoto, Japan) for sending gaseous samples from the system into a gas chromatograph. The components were connected by Teflon (tetrafluoroethylene) tubes. A thin layer of high vacuum grease containing silicone (Dow Corning Toray, Tokyo, Japan) was used as a sealant for the ground glass joints. The total gas volume of the system was $2.8 \mathrm{~L}$. No pressure decrease occurred in the chamber, as the loss of exhaled carbon dioxide absorbed by Ascarite II was automatically compensated for by oxygen. The gaseous samples from this system were analyzed using a Shimadzu model GC-17A gas chromatograph. The start of analysis, the pausing of the pump for gas sampling, and the switching of the sampling valve were controlled by a Shimadzu model Chromatopac C-R7A Plus integrator connected to a Shimadzu model PRG-102A auto analysis system controller.

\subsection{Animals}

Male Sprague-Dawley rats were purchased from Nippon Clea (Osaka, Japan). The animals, weighing 290$340 \mathrm{~g}$, were used when they were 8 or 9 weeks old. Food (Laboratory Chow MF, Oriental Yeast, Japan) and water were available ad libitum, and the environment was maintained at a constant temperature $\left(23^{\circ} \mathrm{C}\right)$ and under a light-dark cycle (light period; 8:00 to 18:00 h) before and after experimentation. During the exposure to the chemicals, both food and water were withheld. All studies were carried out according to the guidelines of the Animal Use and Care Committee of the Osaka Prefectural Institute of Public Health. 


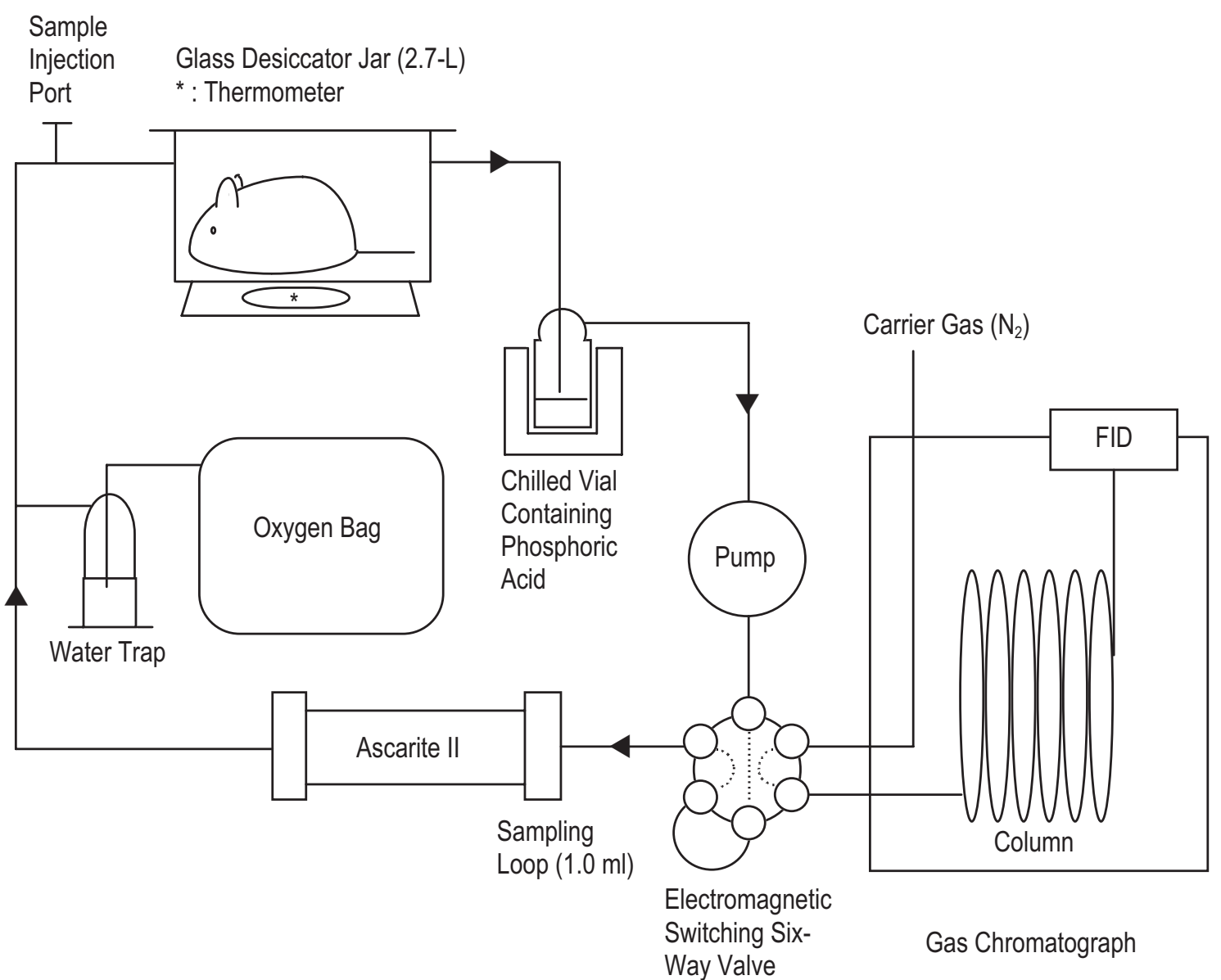

Fig.1 Closed chamber system used for repeated determination of concentrations of $\alpha$-pinene in the chamber air. The total gas volume in the system was $2.8 \mathrm{~L}$.

\subsection{Analysis of $\alpha$-Pinene in a Closed System}

\subsubsection{Estimation of toxicokinetic parameters for} inhalation, exhalation, distribution and metabolic elimination of $\alpha$-pinene for rats:

A rat was placed on a stainless-steel wire net in the glass desiccator jar, and immediately after the system was closed and the pump started, the circulation of air in the system was begun. The rat was allowed about 20 min for acclimation to the system. Measured amounts of $(+)$ - or (-)- $\alpha$-pinene were injected into the system through the sample injection port (Fig. 1) using a microsyringe (Hamilton, NV, USA). The liquid substances were allowed to evaporate immediately by warming the injection port with a hair dryer. For studies with one substance, inhalation runs were conducted with six different injection amounts $(0.1,0.3,1.0,3.0$, 9.0 and $27 \mu 1)$. The different rats were used with each injection.

The gas in the system was sampled periodically by switching the six-way valve equipped with a sampling loop, and the disappearance of the substances from the chamber air was monitored automatically by gas chromatography during the exposures. The rats were continuously exposed to the substances for about 2-6 hours. The gas chromatographic conditions were as follows: analytical column, capillary DB-5 (30 m $\times 0.53$ $\mathrm{mm}$ i.d., $0.5 \mu \mathrm{m}$ film thickness, J\&W Scientific, CA, USA); detector, flame ionization detector (FID; hydrogen, $50 \mathrm{ml} / \mathrm{min}$; air, $500 \mathrm{ml} / \mathrm{min}$; nitrogen as make-up gas, $30 \mathrm{ml} / \mathrm{min}$ ); column oven temperature, $90^{\circ} \mathrm{C}$; detector temperature, $200^{\circ} \mathrm{C}$; carrier gas, nitrogen (flow rate, $10 \mathrm{ml} / \mathrm{min}$ ); sampling interval, $5 \mathrm{~min}$.

\subsubsection{Estimation of rate constants for distribu-} tion and disappearance of $\alpha$-pinene other than by inhalation by rats:

Airborne substances in a closed chamber system can disappear by reversible adsorption to the hair and skin of experimental animals and by adsorption to system 
components $^{26}$, and also by leakage due to repeated sampling for air analysis. To examine the disappearance due to factors other than by inhalation, we used rats with artificially induced respiratory arrest with a single intraperitoneal dose of about $1 \mathrm{ml}$ of Somnopentyl as the control, and the carcass was placed in the glass desiccator jar. The disappearance of the substances from the chamber air was monitored for $6 \mathrm{~h}$ after their injection into the system in a similar manner to that described above to estimate their toxicokinetic parameters for the rats. For studies with one substance, the experiments were conducted with four different injection amounts $(0.1,0.7,4.5$ and $27 \mu \mathrm{l})$.

\subsection{Toxicokinetic Models}

The rat body was considered to consist of two compartments (central and peripheral compartments), and the entire closed chamber system was regarded as having four compartments. The toxicokinetics of $(+)$ and (-)- $\alpha$-pinene were evaluated using a nonlinear four-compartment (chamber air compartment, rat central compartment, rat peripheral compartment and adsorption space compartment) model with MichaelisMenten disappearance kinetics as shown in Fig. 2. As the apparent volumetric flow rates between the two

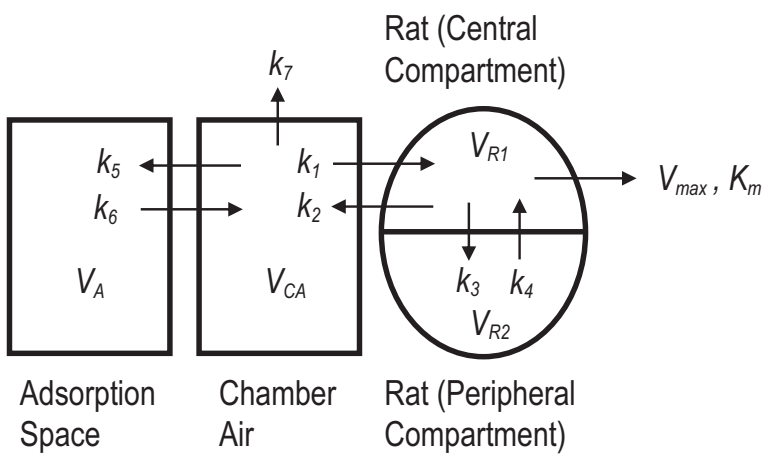

Fig.2 Nonlinear four-compartment model for distribution and metabolism of $\alpha$-pinene. $V_{C A}, V_{A}, V_{R 1}$, and $V_{R 2}$, apparent volumes of distribution for chamber air, adsorption space, and central and peripheral compartments in rat, respectively; $k_{1}$, rate constant in the inhalation process into the central compartment of rat; $k_{2}$, rate constant in the exhalation process from the central compartment; $k_{3}$ and $k_{4}$, rate constants in distribution between central and peripheral compartments; $k_{5}$ and $k_{6}$, rate constants in distribution between chamber air and adsorption space; $k_{7}$, rate constant in the disappearance process from the chamber air; $K_{m}$, Michaelis constant; $V_{\text {max }}$, maximum rate of the metabolic elimination process. compartments are the same, that is, $k_{1} \times V_{C A}=k_{2} \times V_{R l}$, $k_{3} \times V_{R I}=k_{4} \times V_{R 2}$, and $k_{5} \times V_{C A}=k_{6} \times V_{A}$, the following simultaneous differential equations [Eqns $(1-4)$ ] can be derived:

$$
\begin{aligned}
d C_{C A} / d t= & -\left(k_{1}+k_{5}+k_{7}\right) \times C_{C A}+k_{I} \times C_{R I}+k_{5} \times C_{A} \\
d C_{R 1} / d t= & k_{2} \times C_{C A}-\left\{k_{2}+k_{3}+V_{\max } /\left(K_{m}+C_{R I}\right)\right\} \\
& \times C_{R I}+k_{3} \times C_{R 2} \\
d C_{R 2} / d t= & k_{4} \times C_{R I}-k_{4} \times C_{R 2} \\
d C_{A} / d t= & k_{6} \times C_{C A}-k_{6} \times C_{A}
\end{aligned}
$$

where $V_{C A}(2.8 \mathrm{~L}), V_{A}, V_{R I}$ and $V_{R 2}(\mathrm{~L})$ are the apparent volumes of distribution for the chamber air, the adsorption space, and the central and the peripheral compartments in the rat, respectively; $C_{C A}, C_{A}, C_{R I}$ and $C_{R 2}(\mu \mathrm{g} / \mathrm{L})$ are the concentrations of the substance in the chamber air, the adsorption space, and the central and the peripheral compartments in the rat, respectively; $k_{l}, k_{2}, k_{3}-k_{6}$ and $k_{7}(1 / \mathrm{h})$ are rate constants for inhalation, exhalation, distribution and disappearance processes, respectively; $V_{\max }(\mu \mathrm{g} / \mathrm{L} / \mathrm{h})$ is the maximum rate of the metabolic elimination process; and $K_{m}(\mu \mathrm{g} / \mathrm{L})$ is the Michaelis constant. The data of the concentrations in the chamber air for each exposure amount were fitted simultaneously to the model, and the toxicokinetic parameters (rate constants, $V_{\max }$ and $K_{m}$ ) for each substance were estimated by numerically solving the above differential equations with the initial conditions of $C_{A}=C_{R 1}=C_{R 2}=0$ at time zero using a nonlinear least-squares program MULTI (RUNGE), programmed in BASIC for use on a personal computer (Epson Endeavor AT970, Nagano, Japan) by Yamaoka and Nakagawa ${ }^{27)}$.

\subsection{Simulation}

\subsubsection{Verification of estimated values for toxicokinetic parameters:}

The time courses of the concentrations of the substances in the chamber air $\left(C_{C A}\right)$ and the adsorption space $\left(C_{A}\right)$ with the control (dead) rats, and in the chamber air $\left(C_{C A}\right)$, and the central $\left(C_{R l}\right)$ and the peripheral $\left(C_{R 2}\right)$ compartments with the live rats, were simulated using the values of the estimated toxicokinetic parameters in each exposure experiment for the substances by the 
Runge-Kutta-Gill method using a program developed by Yamaoka ${ }^{28)}$.

\subsubsection{Estimation of absorption amounts of $\alpha-$ pinene in rats exposed to low-level concentrations:}

The absorption amounts of the substances in rats exposed to constant low-level concentrations were simulated using the estimated values of the toxicokinetic parameters. The substances were apparently not eliminated by exhalation during exposure to their constant concentrations. Therefore, the apparent amounts of the substances absorbed by inhalation were approximately equivalent to the summation of the amounts of the substances that had disappeared from the body via metabolism by the liver and elimination by the kidney, and the amounts that had accumulated in the body during exposure. Little $\alpha$-pinene was eliminated directly via the kidney ${ }^{13,29)}$. The amounts of the substances that had accumulated in the central and peripheral compartments and the amounts metabolized during exposure to their constant concentrations were simulated using the estimated values of the toxicokinetic parameters for each substance by numerically solving the simultaneous differential equations [Eqns $(5-7)]$ with the initial conditions of $X_{R I}=X_{R 2}=$ $X_{M}=0$ at time zero using the Runge-Kutta-Gill $\operatorname{method}^{28)}$ as follows:

$$
\begin{aligned}
d X_{R 1} / d t= & k_{2} \times C \times V_{R I}-\left\{k_{2}+k_{3}+V_{\max } /\left(K_{m}+X_{R I}\right)\right\} \\
& \times X_{R I}+k_{4} \times X_{R 2} \\
d X_{R 2} / d t= & k_{3} \times X_{R I}-k_{4} \times X_{R 2} \\
d X_{M} / d t= & \left\{V_{\max } /\left(K_{m}+X_{R I}\right)\right\} \times X_{R I}
\end{aligned}
$$

where $X_{R 1}, X_{R 2}$ and $X_{M}(\mu \mathrm{g})$ are the amounts of the substance in the central and the peripheral compartments in the rat and of the substances metabolized, respectively; $C(\mu \mathrm{g} / \mathrm{L})$ is the exposure concentration which should be stipulated; $V_{\max }(\mu \mathrm{g} / \mathrm{h})$ is the maximum rate of the metabolic elimination process; and $K_{m}(\mu \mathrm{g})$ is the Michaelis constant. The other abbreviations are as given above. The value of $V_{R l}$ was calculated by $\left(k_{l} \times\right.$ $\left.V_{C A}\right) / k_{2}$ where $V_{C A}$ is $2.8 \mathrm{~L}$. The values of $V_{\max }(\mu \mathrm{g} / \mathrm{h})$ and $K_{m}(\mu \mathrm{g})$ were obtained by multiplying these estimated values $\left(V_{\max }(\mu \mathrm{g} / \mathrm{L} / \mathrm{h})\right.$ and $\left.K_{m}(\mu \mathrm{g} / \mathrm{L})\right)$ by $V_{R l}$. The absorption amount in the rat $\left(A_{R}, \mu \mathrm{g}\right)$ of a substance during exposure to its constant concentration $(C, \mu \mathrm{g} / \mathrm{L})$ was given by the following equation:

$$
A_{R}=X_{R 1}+X_{R 2}+X_{M}
$$

However, their cumulative amounts preexisted due to daily iterations of indoor (residential) and outdoor (atmospheric) exposures to the substances must also be considered to accurately evaluate the absorption attributed to the substances diffusing from interior materials and building products of the residence. Their cumulative amounts in the central and peripheral compartments of the rat immediately before renewed indoor-exposure to the substances $\left(X_{R I-B}\right.$ and $\left.X_{R 2-B}\right)$ were estimated by repeatedly simulating their absorption for the rat exposed at definite time intervals to indoor and outdoor concentrations of the substances by applying the above method. The absorption amounts attributed to indoor exposure to their concentrations in the residence were simulated using the estimated amounts, $X_{R l-B}$ and $X_{R 2-B}$, as the initial values of $X_{R 1}$ and $X_{R 2}$, respectively.

\subsubsection{Extrapolation of absorption amounts in hu- mans from results with rats:}

Interspecies differences must be considered to extrapolate absorption in humans from the results obtained with the rats. There have been many studies for pharmaceuticals on allometric scaling of pharmacokinetic parameters from animals to humans ${ }^{30-35)}$. Caldwell et al. $^{31)}$ found that the total systemic clearance (per unit body weight) of drugs in humans was $c a$. $16 \%$ of that for rats and the apparent volume of distribution (per unit body weight) in humans was $c a$. $67 \%$ of that for rats by analysis of previous pharmacokinetic data for more than 100 pharmaceuticals. Sawada et $a l .{ }^{33)}$ also showed that the metabolic clearance of drugs in humans was $13 \%$ of that for rats. Similarly, the results by Bachmann et al. ${ }^{30}$ show that the apparent volume of distribution of xenobiotics in humans was ca. $60 \%$ of that for rats. However, there was hardly any available data to compare the apparent volume of distribution and the clearance of the objective $\alpha$-pinene, which were not taken up intentionally unlike pharmaceuticals, between humans and animals. As the volumes of 
distribution of the substances absorbed are closely related to their lipophilicities, it was considered that the rates of the volumes in humans to those in rats would not differ much among chemical compounds. The olive oil/blood partition coefficient (190) of $\alpha$-pinene ${ }^{36)}$ agreed with that (183) for $n$-hexane ${ }^{37)}$. The volume of distribution of $n$-hexane in humans was $c a .62 \%$ of that for $\operatorname{rats}^{38)}$. This value agreed with those for the above pharmaceuticals and xenobiotics. In the present study, the result of Filser et al. ${ }^{38)}$ was applied to the rat to human extrapolation of the apparent volume of distribution for $\alpha$-pinene. The values of the systemic clearance in humans $\mathrm{s}^{39-41)}$ and rats $^{42,43)}$ exposed to styrene were 1.43 (on average) and $11.7 \mathrm{~L} / \mathrm{h} / \mathrm{kg}$, respectively, that is, the value in humans was ca. $12 \%$ of that for rats. The metabolic clearance of $n$-hexane in humans was $11 \%$ of that of rats $^{38)}$. The rates of the clearances in humans to those in rats for these lipophilic compounds as well as $\alpha$-pinene approximately agreed with the rates for the drugs (13-16\%) as mentioned above. The value (11\%) for $n$-hexane was applied to the rat to human extrapolation of the clearance of $\alpha$-pinene, because $\alpha$-pinene consists of an isoprene which is one of the aliphatic hydrocarbons, such as $n$-hexane. The absorption amounts of ( + )- and (-)- $\alpha$-pinene diffusing from the interior materials and building products by a human while at home was calculated on the basis of the following three assumptions:

1. The apparent volume of distribution (per unit body weight) of the substances in humans is $62 \%$ of that of rats.

2. The metabolic clearance (per unit body weight) of $\alpha$ pinene in humans is $11 \%$ of that of rats.

3 . The physiological times in humans and rats are proportional to body-weight ${ }^{0.25}{ }^{44)}$.

Namely, the absorption amounts in humans $\left(A_{H}, \mu \mathrm{g}\right)$ of the substances were calculated by using the following equation:

$$
\begin{aligned}
A_{H}= & \left(X_{R I}+X_{R 2}\right) \times\left(W_{H} / W_{R}\right) \times 0.62+X_{M} \\
& \times\left(W_{H} / W_{R}\right) \times 0.11
\end{aligned}
$$

where $W_{H}$ and $W_{R}(\mathrm{~kg})$ are the body weights for humans and rats, respectively. $X_{R I}$ and $X_{R 2}$ were the amounts of the substance in the central and the peripheral compartments at the rat's physiological time $\left(T_{R}, \mathrm{~h}\right)$ converted to chronological time $\left(T_{H}, \mathrm{~h}\right)$ for humans $\left[T_{H}\right.$ $\left.=T_{R} \times\left(W_{H} / W_{R}\right)^{0.25}:^{44)}\right]$.

\section{RESULTS}

\section{1. Estimation of Toxicokinetic Parameters}

The changes of concentrations of (+)- or (-)- $\alpha-$ pinene in the chamber air were monitored by gas chromatography after their injection into the system with the control rats in order to estimate the rate constants for their distribution to the adsorption space (inner surface of the system, body hair of the rat, etc.) and for their disappearance by dissolution into the phosphoric acid solution and by leakage from the system ( $k_{5}, k_{6}$ and $k_{7}$ in Fig. 2). The concentration-time courses of the substances in the chamber air are shown in Fig. 3 as semilogarithmic plots. The concentrations of both substances decreased exponentially after injection during circulation of the air in the system. The slopes of the curves at steady state after their injection appeared to be constant among the injection amounts. Their rates of decrease were proportional to their concentrations in the chamber air. Therefore, the processes of distribution and disappearance were considered to be linear, and the rate constants $\left(k_{5}, k_{6}\right.$ and $\left.k_{7}\right)$ for each substance were estimated by simultaneously fitting the concentration-time course data for each injection amount of a substance to a linear two-compartment model without the rat compartments in Fig. 2. The estimated values of $k_{5}, k_{6}$ and $k_{7}$ for the substances, shown in Table 1, were used as constant values to estimate the other toxicokinetic parameters of the substances for the biotransformation in rats.

The concentration-time courses of the substances in the chamber air during exposure of the live rats are shown in Fig. 3. The slopes of the curves in steady state after injection of the substances into the closed system appeared to increase with lower exposure concentrations. The rates for disappearance of the substances were not proportional to their concentrations in the chamber air. The slopes of the curves were 
(+)-a-Pinene
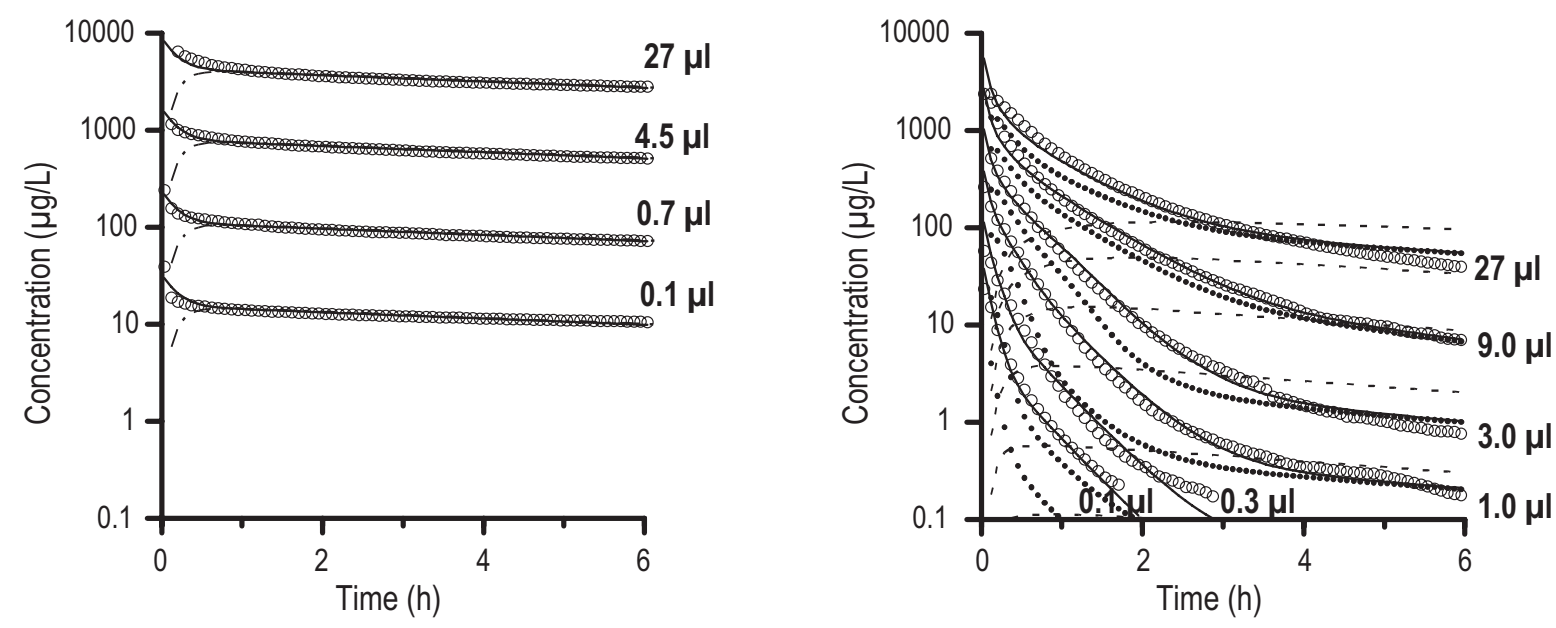

(-)-a-Pinene
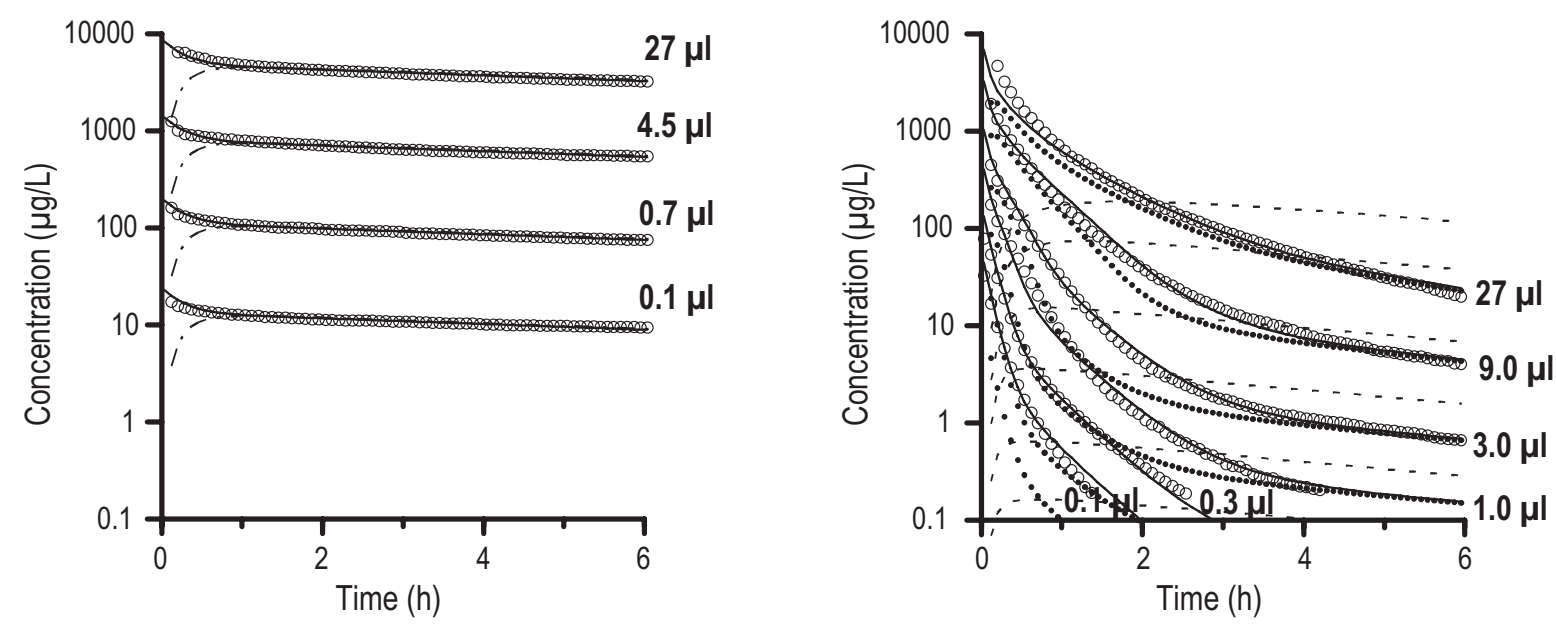

Fig.3 Concentration-time courses of $\alpha$-pinene in the chamber air after injections into the closed system with a dead (left) or live (right) rat $(O)$. The lines were generated by simulation with the toxicokinetic model using the values of the estimated kinetic parameters shown in Table $1 ;-,-\cdots, \cdots \cdots$ and --.- are concentrations of the substances in the chamber air $\left(C_{C A}\right)$, the adsorption space $\left(C_{A}\right)$, and the central $\left(C_{R_{1}}\right)$ and the peripheral $\left(C_{R 2}\right)$ compartments in rat, respectively.

The body weights for dead or live rats used were as follows: $321 \pm 1.9 \mathrm{~g}$ (dead) and $313 \pm 24 \mathrm{~g}$ (live) for (+)$\alpha$-pinene exposure, $316 \pm 3.3 \mathrm{~g}$ (dead) and $306 \pm 19 \mathrm{~g}$ (live) for $(-)-\alpha$-pinene exposure. There were no significant differences between groups.

characteristic for saturation kinetics, namely the disappearance proceeded enzymatically. Furthermore, the substances studied were lipophilic. Therefore, the rat's body was postulated to consist of two compartments (two-compartment rat model) rather than one (onecompartment rat model), and the entire closed system was regarded as having four compartments for the substances. The toxicokinetics of the substances were evaluated using the nonlinear four-compartment model. In practice, the data fitted the two-compartment rat model more accurately than the one-compartment rat model for both substances. The values of the estimated toxicokinetic parameters for each substance in rats are given in Table 1.

\subsection{Simulation}

The concentration-time courses of $\alpha$-pinene in the chamber air, in the adsorption space, and in the central and peripheral compartments in rats were simulated using the values of the estimated toxicokinetic parameters shown in Table 1, and the results are presented in Fig. 3. An accurate fit can be seen for the simulation curves 
for the substances in the chamber air to the experimental data. The absorption amounts of each substance were estimated in rats exposed to $50 \mu \mathrm{g} / \mathrm{m}^{3}$ for $12 \mathrm{~h}$ using the estimated values of the toxicokinetic parameters on the assumption that the compartment model used was also suitable outside the exposure concentration range tested in this study. The absorption amounts were estimated to be 38 and $40 \mu \mathrm{g}$ per $1 \mathrm{~kg}$ of rat body weight for (+)- and (-)- $\alpha$-pinene, respectively, namely showing approximate agreement between the enantiomers (Table 2).

\subsection{Extrapolation}

We had previously examined indoor air concentrations of volatile chemicals containing $\alpha$-pinene in 105 Japanese residences under conventional living conditions $^{3)}$. Their outdoor (atmospheric environment) concentrations had also been measured in our other study $^{45}$. As the indoor and outdoor concentrations of $\alpha$ pinene had been quantified in these studies as a mixture of the enantiomers, in the present study, the half values were assumed to be the concentrations of each enantiomer in both indoor and outdoor air; the values of indoor (median and maximum) and outdoor (median) concentrations are presented in Table 3. The absorption amounts of $\alpha$-pinene diffusing from the interior materials and building products in the residences under usual living conditions were estimated for humans with continuous exposure at home under these conditions of indoor and outdoor air pollution, and the results are shown in Table 3 with the values converted to the absorption amount per $60 \mathrm{~kg}$ of human body weight. The absorption amounts for $16 \mathrm{~h}$, which is the average time spent at home by the Japanese ${ }^{1)}$, were estimated to be $15 \mu \mathrm{g}$ for (+)- $\alpha$-pinene and $16 \mu \mathrm{g}$ for $(-)-\alpha$ pinene in a residence polluted by mid-level concentrations. A full-time housewife who spends a long time in a residence ( $20 \mathrm{~h} /$ day) was estimated to absorb about $38 \mu \mathrm{g}$ or $16 \mathrm{mg}$ as the total amount of $\alpha$ pinene in a residence polluted by mid-level $\left(4.4 \mu \mathrm{g} / \mathrm{m}^{3}\right)$ and high-level $\left(1.8 \mathrm{mg} / \mathrm{m}^{3}\right)$ concentrations, respectively.

\section{DISCUSSION}

The inhalation toxicokinetics of (+)- and (-)- $\alpha-$ pinene were evaluated for rats using a nonlinear fourcompartment model, and the absorption amounts of the substances were extrapolated for humans exposed to their lower concentrations in residences on the basis of the results obtained with the rats. The absorption amounts of the two enantiomers were estimated to be

Table 1 Toxicokinetic parameters for transformation of $\alpha$-pinene

\begin{tabular}{cccccccccc}
\hline \hline & $k_{1}$ & $k_{2}$ & $k_{3}$ & $k_{4}$ & $k_{5}$ & $k_{6}$ & $k_{7}$ & $V_{\max }$ & $k_{m}$ \\
& $(1 / \mathrm{h})$ & $(1 / \mathrm{h})$ & $(1 / \mathrm{h})$ & $(1 / \mathrm{h})$ & $(1 / \mathrm{h})$ & $(1 / \mathrm{h})$ & $(1 / \mathrm{h})$ & $(\mu \mathrm{g} / \mathrm{L} / \mathrm{h})$ & $(\mu \mathrm{g} / \mathrm{L})$ \\
\hline$(+)-\alpha$-Pinene & 8.18 & 7.42 & 4.92 & 0.150 & 2.68 & 3.00 & 0.142 & 245 & 5.31 \\
$(-)-\alpha$-Pinene & 8.70 & 8.34 & 4.24 & 0.186 & 1.57 & 2.34 & 0.114 & 761 & 18.4 \\
\hline
\end{tabular}

Table 2 Estimated amounts of $\alpha$-pinene and typical indoor air contaminants absorbed in rats exposed to $50 \mu \mathrm{g} / \mathrm{m}^{3}$ for $12 \mathrm{~h}$

\begin{tabular}{lcll}
\hline \hline$(+)-\alpha$-Pinene & 38 & $(-)-\alpha$-Pinene & 40 \\
\hline$n$-Hexane & $7.3^{a}$ & 0 -Xylene & $22^{b}$ \\
$n$-Heptane & $14^{a}$ & $m$-Xylene & $21^{b}$ \\
$n$-Nonane & $20^{a}$ & $p$-Xylene & $32^{b}$ \\
$n$-Decane & $22^{a}$ & Styrene & $34^{b}$ \\
Toluene & $25^{b}$ & $1,2,4-$ Trimethylbenzene & $39^{b}$ \\
Ethylbenzene & $28^{b}$ & & \\
\hline
\end{tabular}

The values were converted to the absorbed amount per $1 \mathrm{~kg}$ of rat body weight $(\mu \mathrm{g} / \mathrm{kg})$.

${ }^{a}$ The values are cited from our previous paper ${ }^{19)}$.

${ }^{b}$ The values are cited from our previous paper ${ }^{25}$. 
approximately equal in rats exposed to concentrations of $50 \mu \mathrm{g} / \mathrm{m}^{3}$ for $12 \mathrm{~h}$ (Table 2). In the study with human volunteers by Falk et al. ${ }^{13)}$, no significant differences in uptake, distribution or elimination were found between the enantiomers. Therefore, the kinetics of $\alpha$ pinene is likely to be the same between the enantiomers in mammals, although there is difference in their toxic activities ${ }^{17,18)}$. The estimated amounts of absorbed $\alpha$-pinene were compared with those for aliphatic or aromatic hydrocarbons examined by using the same experimental method in our previous studies (Table 2) ${ }^{19,25)}$. In the studies, the absorption amounts of the substances had been suggested to show a tendency to increase with the number of carbon atoms in their chemical structures for each chemical class. $\alpha$-Pinene was estimated to be absorbed more easily than the normal alkanes with $\mathrm{C} 6-\mathrm{C} 10$ or aromatics with C7-C8 which are typical indoor air contaminants, and to be absorbed nearly equally to 1,2,4-trimethylbenzene (C9), which is a more lipophilic aromatic.

The indoor and outdoor concentrations in Japan of the aliphatic or aromatic hydrocarbons as well as $\alpha$ pinene were examined in our previous studies ${ }^{3,45}$. The absorption amounts of substances diffusing from the interior materials and building products in residences under usual living conditions were estimated for humans under these conditions of indoor and outdoor air pollution by using the values of their toxicokinetic parameters obtained by the same method as the present study ${ }^{19,25)}$, and the results are shown in Table 4. Extrapolation of the absorption amount of $\alpha$-pinene, $31 \mu \mathrm{g}$ as the total amount for the two enantiomers during $16 \mathrm{~h}$, shown in Table 3, gave the highest value next to toluene $(102 \mu \mathrm{g})$ and gave the same level as the total amounts for three isomers of xylene for humans living in a Japanese residence in which the indoor air was polluted by mid-level concentrations of the substances. In a residence where air pollution was marked, the total amount of $\alpha$-pinene $(13 \mathrm{mg}$ ) absorbed over $16 \mathrm{~h}$ was much more than those of other substances (Table 3 and 4), and was $c a$. 10 times of that for $n$-nonane (1.4 $\mathrm{mg}$ ) which was maximum among the absorption amounts of the hydrocarbons studied. Therefore, $\alpha$ pinene was considered to be one of the volatile organic compounds most abundantly absorbed in a Japanese residence. The Environmental Protection Agency (EPA) ${ }^{46)}$ proposed No Observed Adverse Effect Level (NOAEL) of 21 (male) or 170 (female) $\mathrm{mg} / \mathrm{kg}$ body weight per day for $\alpha$-pinene by inhalation on the basis of results for rats tested in the National Toxicology Program ${ }^{47)}$. As the values of Tolerable Daily Intake (TDI) of xenobiotics are usually calculated by NOAEL/ $(10 \times 10)$, the values for $\alpha$-pinene were extrapolated to be $13 \mathrm{mg}$ (male) or $102 \mathrm{mg}$ (female) per $60 \mathrm{~kg}$ of human body weight. The absorption amount of $\alpha$-pinene by a human spending $16 \mathrm{~h}$ at home where air pollution was marked came to the same level as the TDI for males. Consequently, $\alpha$-pinene was suggested to be the most noteworthy indoor air pollutant of Japanese residences, especially in new wooden residences ${ }^{3)}$, from the viewpoint of the effect on health.

The pulmonary uptake rate $\left(U_{H}, \%\right)$ of each enantiomer of $\alpha$-pinene in a human while at home polluted by mid-level $\left(2.2 \mu \mathrm{g} / \mathrm{m}^{3}\right)$ and high-level $(0.9 \mathrm{mg} /$ $\mathrm{m}^{3}$ ) concentrations of the substances was calculated from the results shown in Table 3 according to the following equations [Eqns $(10,11)]$ :

$$
\begin{aligned}
& U_{H}=A_{H} / I_{H} \times 100 \\
& I_{H}=C_{E} \times V P / 1000 \times t
\end{aligned}
$$

where $A_{H}$ is the absorption amount estimated for humans $(\mu \mathrm{g}) ; I_{H}$ is total pulmonary intake $(\mu \mathrm{g}) ; C_{E}$ is exposure concentration $\left(\mu \mathrm{g} / \mathrm{m}^{3}\right) ; V P$ is pulmonary ventilation $(\mathrm{L} / \mathrm{min}) ; t$ is duration of exposure ( $\mathrm{min})$. The values for $A_{H}, C_{E}$ (indoor concentration) and $t$ were from Table 3. The value of $V P$ for a Japanese resident was assumed to be $12.5 \mathrm{~L} / \mathrm{min}^{48)}$. The values of the uptake rate for $(+)-\alpha$-pinene were calculated to be $58 \%$ and 57\% while at home (indoor concentration: $2.2 \mu \mathrm{g} /$ $\mathrm{m}^{3}$ ) for 12 and $24 \mathrm{~h}$, respectively, and similarly the values for (-)- $\alpha$-pinene were $60 \%$ and $59 \%$ for 12 and 24 $\mathrm{h}$, respectively. The values were calculated to be rarely different in the residences polluted by high-level $(0.9$ $\left.\mathrm{mg} / \mathrm{m}^{3}\right)$ concentrations of both (+)- and (-)- $\alpha$-pinene. The uptake rates for human volunteers exposed to $(+)$ $\alpha$-pinene $\left(10,225,450 \mathrm{mg} / \mathrm{m}^{3}\right)$ or $(-)$ - $\alpha$-pinene $(450$ $\left.\mathrm{mg} / \mathrm{m}^{3}\right)$ during light physical exercise $(50 \mathrm{~W})$ for $2 \mathrm{~h}$ 
Table 3 Extrapolated amounts absorbed by a Japanese resident exposed to $\alpha$-pinene diffusing from interior materials and building products in his/her residence

\begin{tabular}{|c|c|c|c|c|c|c|c|c|c|}
\hline & \multirow{3}{*}{$\begin{array}{l}\text { Outdoor conc. } \\
\left(\text { median, } \mu \mathrm{g} / \mathrm{m}^{3}\right)^{a}\end{array}$} & \multirow{3}{*}{$\begin{array}{l}\text { Indoor conc. } \\
\left(\text { median, } \mu \mathrm{g} / \mathrm{m}^{3}\right)^{b}\end{array}$} & \multicolumn{3}{|c|}{ Absorption amounts $(\mu \mathrm{g})^{c}$} & \multirow{3}{*}{$\begin{array}{l}\text { Indoor conc. } \\
\left(\max ., \mu g / \mathrm{m}^{3}\right)^{b}\end{array}$} & \multirow{2}{*}{\multicolumn{3}{|c|}{$\begin{array}{c}\text { Absorption amounts }(\mu \mathrm{g})^{c} \\
\text { Time at home }\end{array}$}} \\
\hline & & & \multicolumn{3}{|c|}{ Time at home } & & & & \\
\hline & & & $12 \mathrm{~h}$ & $16 \mathrm{~h}$ & $20 \mathrm{~h}$ & & $12 \mathrm{~h}$ & $16 \mathrm{~h}$ & $20 \mathrm{~h}$ \\
\hline$(+)-\alpha$-Pinene & 0.27 & 2.2 & 11 & 15 & 19 & 900 & 4737 & 6220 & 7643 \\
\hline$(-)-\alpha$-Pinene & 0.27 & 2.2 & 12 & 16 & 19 & 900 & 4923 & 6461 & 7938 \\
\hline
\end{tabular}

As the indoor and outdoor concentrations of $(+)$ - and (-)- $\alpha$-pinene were quantified as a mixture, the half values were assumed to be the concentrations of each substance.

${ }^{a}$ The values are cited from our previous paper ${ }^{45)}$.

${ }^{b}$ The values are cited from our previous paper".

${ }^{c}$ The values are converted to the absorption amount per $60 \mathrm{~kg}$ of human body weight.

Table 4 Extrapolated amounts absorbed by a Japanese resident exposed to typical indoor air contaminants diffusing from interior materials and building products in his/her residence for $16 \mathrm{~h}$

\begin{tabular}{l|c|cc|cc}
\hline \hline & $\begin{array}{c}\text { Outdoor conc. } \\
\left(\text { median, } \mu \mathrm{g} / \mathrm{m}^{3}\right)^{b}\end{array}$ & $\begin{array}{c}\text { Indoor conc. } \\
\left(\text { median, } \mu \mathrm{g} / \mathrm{m}^{3}\right)^{c}\end{array}$ & $\begin{array}{c}\text { Absorption amounts } \\
(\mu \mathrm{g})^{d}\end{array}$ & $\begin{array}{c}\text { Indoor conc. } \\
\left(\mathrm{max} ., \mu \mathrm{g} / \mathrm{m}^{3}\right)^{c}\end{array}$ & $\begin{array}{c}\text { Absorption amounts } \\
(\mu \mathrm{g})^{d}\end{array}$ \\
\hline$n$-Hexane & 2.4 & 2.5 & 3.2 & 77 & 105 \\
$n$-Heptane & 1.0 & 2.2 & 5.7 & 194 & 510 \\
$n$-Nonane & 0.98 & 1.9 & 7.8 & 336 & 1412 \\
-Decane & 1.6 & 2.8 & 12 & 217 & 981 \\
Toluene & 16 & 22 & 102 & 145 & 718 \\
Ethylbenzene & 2.7 & 4.7 & 24 & 50 & 267 \\
o-Xylene & 0.97 & 2.0 & 8.1 & 55 & 238 \\
$m$-Xylene ${ }^{a}$ & 1.6 & 2.8 & 11 & 56 & 226 \\
$p$-Xylene ${ }^{a}$ & 1.6 & 2.8 & 16 & 56 & 317 \\
Styrene & 0.028 & 0.11 & 0.72 & 22 & 145 \\
1,2,4-Trimethylbenzene & 1.5 & 2.5 & 18 & 69 & 515 \\
\hline
\end{tabular}

${ }^{a}$ As the indoor and outdoor concentrations of $m$ - and $p$-xylene were quantified as a mixture, the half values were assumed to be the concentrations of each substance.

${ }^{b}$ The values are cited from our previous paper ${ }^{45)}$.

${ }^{c}$ The values are cited from our previous paper".

${ }^{d}$ The values are converted to absorption amount per $60 \mathrm{~kg}$ of human body weight.

had been as follows: $40 \%$ for $10 \mathrm{mg} / \mathrm{m}^{3}$ of $(+)-\alpha-$ pinene, $60 \%$ for $225 \mathrm{mg} / \mathrm{m}^{3}$ of (+)- $\alpha$-pinene, $58 \%$ for $450 \mathrm{mg} / \mathrm{m}^{3}$ of (+)- and (-)- $\alpha$-pinene ${ }^{13)}$. The values for the two higher exposure concentrations are in agreement with our results.

No guideline value for indoor $\alpha$-pinene concentration has yet been recommended in Japan. However, the absorption amount of $\alpha$-pinene in a human in a Japanese residence, where air pollution was marked, was estimated to be the same level as the TDI calculated from the NOAEL proposed by the EPA ${ }^{46)}$. Furthermore, $\alpha$ pinene was clarified to be significantly related to SBS in newly built Japanese dwellings ${ }^{9,10}$. Therefore, it was considered that the guideline value for indoor $\alpha$-pinene should be established to prevent the adverse effects on health in the residents.

\section{References}

1) National Institute of Advanced Industrial Science and Technology (AIST), Research Center for Chemical Risk Management, Risk Assessment Tools, Japanese Exposure Factors Handbook, At home (2007). (http://unit.aist.go.jp/riss/crm/ exposurefactors/documents/factor/time_activities/ indoor_time.pdf)

2) Yoshida T., Andoh K. and Matsunaga I.: Seasonal 
variation of airborne concentrations of formaldehyde and volatile organic compounds in residences. Bull. Osaka Pref. Inst. Publ. Health, 39, 31-48 (2001).

3) Yoshida T., Matsunaga I., Oda H., Miyake Y., Sasaki S., Ohya Y., Miyamoto S. and Hirota Y.: Residential air pollution by chemicals (HCHO, $\mathrm{NO}_{2}$, VOC and SVOC) under normal living conditions in Osaka prefecture. J. Soc. Indoor Environ. Jpn., 9, 83-95 (2007).

4) Tanaka-Kagawa T., Ushiyama S., Matsushima E., Sasaki A., Kobayashi H., Kobayashi H., Yagi M., Tsuno M., Arao M., Ikemoto K., Yamasaki M., Nakashima A., Shimizu Y., Otsubo Y., Ando M., Jinno H. and Tokunaga H.: Survey of volatile organic compounds found in indoor and outdoor air samples from Japan. Bull. Natl. Inst. Health Sci., 123, 27-31 (2005).

5) Ando M.: Indoor air and human health - Sick house syndrome and multiple chemical sensitivity -. ibid, 120, 6-38 (2002).

6) Yoshida T. and Matsunaga I.: Present state and issues of official analysis methods concerning indoor air pollution by organic compounds. Bull. Osaka Pref. Inst. Publ. Health, 45, 89-97 (2007).

7) Ujiie A., Kikuchi H., Hayashi K. and Hamana T.: Indoor air pollution in temporary prefabricated school buildings. Ann. Rep Miyagi Pref. Inst. Publ. Health Environ., 27, 48-51 (2009).

8) Takeuchi S., Kojima H., Kobayashi S. and Jin K.: Survey of indoor air chemicals related with the symptoms of a patient with multiple chemical sensitivity (part II) - A case study of a house wife who lives in Sapporo -. Rep. Hokkaido Inst. Publ. Health, 55, 7-14 (2005).

9) Saijo Y., Kishi R., Sata F., Katakura Y., Urashima Y., Hatakeyama A., Kobayashi S., Jin K., Kurahashi N., Kondo T., Gong Y.Y. and Umemura T.: Symptoms in relation to chemicals and dampness in newly built dwellings. Int. Arch. Occup. Environ. Health, 77, 461-470 (2004).

10) Takeda M., Saijo Y., Yuasa M., Kanazawa A., Araki A. and Kishi R.: Relationship between sick building syndrome and indoor environmental factors in newly built Japanese dwellings. ibid, 82, 583-593 (2009).

11) Seifert B,: Volatile organic compounds. In: Indoor Air Quality, A Comprehensive Reference Book, Air Quality Monographs, eds. M. Maroni, B. Seifert, T. Lindvall, vol. 3, Elsevier Science, the Netherlands, p. 819-821 (1995).

12) Demers P.A., Teschke K., Davies H.W., Kennedy S.M. and Leung V.: Exposure to dust, resin acids, and monoterpenes in softwood lumber mills. Am. Ind. Hyg. Assoc. J., 61, 521-528 (2000).

13) Falk A.A., Hagberg M.T., Lof A.E., WigaeusHjelm E.M. and Zhiping W.: Uptake, distribution and elimination of $\alpha$-pinene in man after exposure by inhalation. Scand. J. Work Environ. Health, 16, 372-378 (1990).

14) Budavari S., O'Neil M.J., Smith A., Heckelman P.E. and Kinneary J.F.: The Merck Index, An Encyclopedia of Chemicals, Drugs, and Biologicals, 12th Ed., Merck, Whitehouse Station, NJ, USA (1996).

15) Roe F.J.C. and Pierce W.: Tumor promotion by citrus oils: Tumors of the skin and urethral orifice in mice. J. Nat. Cancer Inst., 24, 1389-1403 (1960).

16) Rous P. and Kidd J.G.: Conditional neoplasms and subthreshold neoplastic states. A study of tar tumors of rabbits. J. Exp. Med., 73, 365-390 (1941).

17) Kasanen J.P., Pasanen A.L., Pasanen P., Liesivuori J., Kosma V.M. and Alarie Y.: Stereospecificity of the sensory irritation receptor for nonreactive chemicals illustrated by pinene enantiomers. Arch. Toxicol., 72, 514-523 (1998).

18) Nielsen G.D., Larsen S.T., Hougaard K.S., Hammer M., Wolkoff P., Clausen P.A., Wilkins C.K. and Alarie Y.: Mechanisms of acute inhalation effects of $(+)$ and $(-)-\alpha$-pinene in BALB/c mice. Basic Clin. Pharmacol. Toxicol., 96, 420-428 (2005).

19) Yoshida T.: Approach to estimation of absorption of aliphatic hydrocarbons diffusing from interior materials in an automobile cabin by inhalation toxicokinetic analysis in rats. J. Appl. Toxicol., 30, 42-52 (2010).

20) Yoshida T., Andoh K. and Fukuhara M.: 
Estimation of absorption of environmental contaminants in low-level exposure by pharmacokinetic analysis. J. Toxicol. Environ. Health A, 54, 145158 (1998).

21) Yoshida T., Andoh K. and Fukuhara M.: Estimation of absorption of trihalomethanes and carbon tetrachloride in low-level exposure by inhalation pharmacokinetic analysis in rats. Arch. Environ. Contam. Toxicol., 36, 347-354 (1999).

22) Eriksson K.A., Levin J.O., Sandstrom T., Lindstrom-Espeling K., Linden G. and Stjernberg N.L.: Terpene exposure and respiratory effects among workers in Swedish joinery shops. Scand. J. Work Environ. Health, 23, 114-120 (1997).

23) Eriksson K. and Levin J.O.: Identification of cis- and trans-verbenol in human urine after occupational exposure to terpenes. Int. Arch. Occup. Environ. Health, 62, 379-383 (1990).

24) Edman K., Lofstedt H., Berg P., Eriksson K., Axelsson S., Bryngelsson I. and Fedeli C.: Exposure assessment to $\alpha$ - and $\beta$-pinene, $\Delta^{3}$-carene and wood dust in industrial production of wood pellets. Ann. Occup. Hyg., 47, 219-226 (2003).

25) Yoshida T.: Estimation of absorption of aromatic hydrocarbons diffusing from interior materials in automobile cabins by inhalation toxicokinetic analysis in rats. J. Appl. Toxicol., 30, 525-535 (2010).

26) Dennison J.E., Andersen M.E. and Yang R.S.H.: Pitfalls and related improvements of in vivo gas uptake pharmacokinetic experimental systems. Inhal. Toxicol., 17, 539-548 (2005).

27) Yamaoka K. and Nakagawa T.: A nonlinear least squares program based on differential equations, MULTI (RUNGE), for microcomputers. J. Pharm. Dyn., 6, 595-606 (1983).

28) Yamaoka K.: Maikon ni yoru yakubutsu tainai doutai kaiseki hou, Nankoudou, Tokyo, p. 43-53 (1984).

29) Levin J.O., Eriksson K., Falk A. and Lof A.: Renal elimination of verbenols in man following experimental $\alpha$-pinene inhalation exposure. Int. Arch. Occup. Environ. Health, 63, 571-573 (1992).

30) Bachmann K., Pardoe D. and White D.: Scaling basic toxicokinetic parameters from rat to man. Environ. Health Perspect., 104, 400-407 (1996).

31) Caldwell G.W., Masucci J.A., Yan Z. and Hageman W.: Allometric scaling of pharmacokinetic parameters in drug discovery: Can human CL, $\mathrm{V}_{\mathrm{ss}}$ and $\mathrm{t}_{1 / 2}$ be predicted from in-vivo rat data? Eur. J. Drug Metab. Pharmacokinet., 29, 133-143 (2004).

32) Mahmood I. and Balian J.D.: Interspecies scaling: A comparative study for the prediction of clearance and volume using two or more than two species. Life Sci., 59, 579-585 (1996).

33) Sawada Y., Hanano M., Sugiyama Y. and Iga T.: Prediction of the disposition of nine weakly acidic and six weakly basic drugs in humans from pharmacokinetic parameters in rats. J. Pharmacokin. Biopharm., 13, 477-492 (1985).

34) Ward K.W. and Smith B.R.: A comprehensive quantitative and qualitative evaluation of extrapolation of intravenous pharmacokinetic parameters from rat, dog, and monkey to humans. I. Clearance. Drug Matabol. Dispos., 32, 603-611 (2004).

35) Ward K.W. and Smith B.R.: A comprehensive quantitative and qualitative evaluation of extrapolation of intravenous pharmacokinetic parameters from rat, dog, and monkey to humans. II. Volume of distribution and mean residence time. ibid, 32, 612-619 (2004).

36) Falk A., Gullstrand E., Lof A. and Wigaeus-Hjelm E.: Liquid/air partition coefficients of four terpenes. Br. J. Ind. Med. 47, 62-64 (1990).

37) Perbellini L., Brugnone F., Caretta D. and Maranelli G.: Partition coefficients of some industrial aliphatic hydrocarbons (C5 - C7) in blood and human tissues. ibid, 42, 162-167 (1985).

38) Filser J.G., Peter H., Bolt H.M. and Fedtke N.: Pharmacokinetics of the neurotoxin $n$-hexane in rat and man. Arch. Toxicol., 60, 77-80 (1987).

39) Wenker M.A.M., Kezic S., Monster A.C. and Wolff de F.A.: Metabolic capacity and interindividual variation in toxicokinetics of styrene in volunteers. Hum. Exp. Toxicol., 20, 221-228 (2001).

40) Wigaeus E., Lof A., Bjurstrom R. and Nordqvist M.B.: Exposure to styrene. Uptake, distribution, metabolism and elimination in man. Scand. J. 
Work Environ. Health, 9, 479-488 (1983).

41) Wigaeus E., Lof A. and Nordqvist M.B.: Uptake, distribution, metabolism, and elimination of styrene in man. A comparison between single exposure and co-exposure with acetone. Br. J. Ind. Med., 41, 539-546 (1984).

42) Ramsey J.C. and Young J.D.: Pharmacokinetics of inhaled styrene in rats and humans. Scand. J. Work Environ. Health, 4, Suppl. 2, 84-91 (1978).

43) Young J.D., Ramsey J.C., Blau G.E., Karbowski R.J., Nitschke K.D., Slauter R.W. and Braun W.H.: Pharmacokinetics of inhaled or intraperitoneally administered styrene in rats. In: Toxicology and Occupational Medicine, Proceedings of the Tenth Inter-American Conference on Toxicology and Occupational Medicine, organizer W.B. Deichmann, Elsevier/North Holland, New York, p. 297-310 (1979).

44) Krishnan K. and Andersen M.E.: Interspecies scaling in pharmacokinetics. In: New Trends in Pharmacokinetics, eds. A. Rescigno, A.K. Thakur, Plenum Press, New York, p. 203-226 (1991).

45) Yoshida T. and Matsunaga I.: A case study on iden- tification of airborne organic compounds and time courses of their concentrations in the cabin of a new car for private use. Environ. Int., 32, 58-79 (2006).

46) Environmental Protection Agency (EPA): The flavor and fragrance high production volume consortia, The terpene consortium, revised test plan for bicyclic terpene hydrocarbons, EPA, Washington DC (2006). (http://www.epa.gov/HPV/pubs/ summaries/bictrphy/c13610rt.pdf)

47) National Toxicology Program (NTP): Initial study results from a 90 day toxicity study on alphapinene in mice and rats, Study number SRL-13 wk 03AP/M and SRL-13 wk 03AP/R, National Institute of Environmental Health Sciences, Research Triangle Park, NC (2006).

48) National Institute of Advanced Industrial Science and Technology (AIST), Research Center for Chemical Risk Management, Risk Assessment Tools, Japanese Exposure Factors Handbook, Breathing rate (2007). (http://unit.aist.go.jp/riss/ crm/exposurefactors/documents/factor/body/ breathing_rate.pdf) 